Slavisticheskie chteniia pamiati prof. P. A. Dmitrieva i prof. G. I. Safronova: Materialy mezhdunarodnoi nauchnoi konferentsii 12-14 sentiabria 2000 g. / Otv. red. M. Iu. Kotova, Sankt-Peterburg: Filologicheskii fakul'tet SPbGU, 2001.

Slavisticheskie chteniia pamiati professora P. A. Dmitrieva i professora G. I. Safronova: Materialy mezhdunarodnoi nauchnoi konferentsii 12-14 sentiabria 2001 g. / Otv. red. M. Iu.Kotova, Sankt-Peterburg: Filologicheskii fakul'tet SPbGU, 2002.

Slavisticheskie chteniia pamiati professora P. A. Dmitrieva i professora G. I. Safronova: Materialy mezhdunarodnoi nauchnoi konferentsii 12-14 sentiabria 2002 g. / Otv. red. M. Iu. Kotova, Sankt-Peterburg: Filologicheskii fakul'tet SPbGU, 2003.

Slavisticheskie chteniia pamiati professora P. A. Dmitrieva i professora G. I. Safronova: Materialy mezhdunarodnoi nauchnoi konferentsii 11-13 sentiabria 2003 g. / Otv. red. E. Iu. Ivanova, Sankt-Peterburg: Filologicheskii fakul'tet SPbGU, 2004.

Slavisticheskie chteniia pamiati professora P. A. Dmitrieva i professora G. I. Safronova: Materialy mezhdunarodnoi nauchnoi konferentsii 9-11 sentiabria 2004 g. / Otv. red.y E. Iu. Ivanova, M. Iu. Kotova, Sankt-Peterburg: Filologicheskii fakul'tet SPbGU, 2005.

Slavisticheskie chteniia pamiati prof. P. A. Dmitrieva i prof. G. I. Safronova. Slavianskaia filologiia v sovremennoi sisteme universitetskogo obrazovaniia. Materialy mezhdunarodnoi nauchnoi konferentsii 12-13 sentiabria 2006 goda / Otv. red. M. Iu. Kotova, Sankt-Peterburg: Izdatel'skii dom Sankt-Peterburgskogo universiteta, 2007.

Slavisticheskie chteniia pamiati prof. P. A. Dmitrieva i prof. G. I. Safronova: Materialy mezhvuzovskoi nauchnoi konferentsii 12-13 sentiabria 2007 goda / Otv. red. M. I. Kotova, Sankt-Peterburg: Fakul'tet filologii i iskusstv SPbGU, 2008.

Slavisticheskie chteniia pamiati professora P. A. Dmitrieva i prof. G. I. Safronova: Materialy mezhvuzovskoi nauchnoi konferentsii 12-13 sentiabria 2008 goda / Otv. red. M. Iu. Kotova, Sankt-Peterburg: Fakul'tet filologii i iskusstv SPbGU, 2010.

Aliona Shestakova-Stukun

ORCID: 0000-0002-0674-1374

Petersburski Uniwersytet Państwowy

\title{
12th Interdisciplinary Colloquium on Proverbs, 4-11 November 2018, Tavira, Portugal
}

Tavira is a picturesque coastal fishing and holiday city in the south of Portugal; and it possesses the proud title of the world capital of proverbs. Fully supported by the local authorities, the city hosted this year the 12th Interdisciplinary Colloquium on Proverbs of the International Association of Paremiology (AIP-IAP),${ }^{1}$ welcoming participants from 28 countries all around the globe, ${ }^{2}$ including first-time attendees from New Zealand and Turkey.

1 http://www.colloquium-proverbs.org/icp/en/ (accessed: 7.12.2018).

2 Participating countries: Angola, Argentina, Belgium, Brazil, Croatia, Czech Republic, Estonia, Finland, Germany, Greece, Hungary, India, Iran, Ireland, Morocco, New Zealand, Nigeria, Norway, Poland, Portugal, Romania, Russia, South Africa, Spain, The Netherlands, Turkey, UK, USA. 
The high level of the Colloquium is guaranteed by the multiannual participation of such renowned academics as Wolfgang Mieder (USA) and František Čermák (Czech Republic). This year the thematic set-up of the Colloquium moved from "interdisciplinary" to paremiological, i.e. the majority of the presentations analyzed strictly paremiological subjects, and a smaller part was dedicated to the general role of proverbs in literature and society. Given the meeting venue and the enthusiasm of the organizers, the Portuguese/ Brazilian input was traditionally significant.

\section{Presentations' overview}

Mieder participated this year as an absentee reporter presenting a paper "In provebiis non semper veritas: Reflections on the reprint of an anti-Semitic proverb collection." This paper induced a high professional interest, but not only: it also generated an emotional reaction in the audience. There are superb Yiddish and Jewish/Hebrew proverb collections and serious studies on this rich repertoire of proverbs, says Mieder. But starting from the 19th century and especially during the National Socialism period in Germany the traditional proverbs and invented pseudo-proverbs discrediting the Jewish population were used to manipulate public opinion by claiming that these proverbial stereotypes express absolute proverbial truths. Reacting at the highly questionable reprint in 2016 of Ernst Hiemer's anti-Semitic proverb collection Der Jude im Sprichwort der Volker (The Jew in the proverbs of the people, 1942), Mieder warns about the danger of fuelling presentday anti-Semitism.

The matter of Jews-related jokes and proverbs was also mentioned by Karel Kučera (Czech Republic) in his presentation "Proverbs under the five-pointed star, the sickle and the hammer." He made a comparison between the use of proverbs in two totalitarian political systems - Nazism and socialism, referring to Mieder's study Proverbs in Nazi Germany.

Čermák presented a paper on "Basic English proverbs: Their variability and corpus-based aspects." Searching for proverbs in the British National Corpus, which contains 6 million words, his aim was to understand what is basic there. The more than 100 English proverbs with their context, frequency, variability and thematic evaluation serve as a future candidate for Matti Kuusi's international type system of proverbs. ${ }^{3}$ (Besides presenting his own paper, Čermák was one of the most active participants in discussions on the other presentations; by raising well formulated questions and making valuable remarks he contributed significantly to the brainstorming on different subjects).

Fionulla Carson Williams (Ireland) also searched for proverbs in archives - in the National Folklore Collection, University of College of Dublin ${ }^{4}$ ("Yellow silk on Judy... the exotic in twentieth-century proverbs in Ireland"). From the beginning she realized that there were numerous references to things beyond everyday life in rural Ireland, where most of the respondents lived. Velvet, silk and satin, cake, wine and grapes, lions and camels... ("Yellow silk on Judy and patches on her father," "Silk and satin, scarlet and velvet often put out the kitchen fire," "The last straw breaks the camel's back"). In her paper, Carson Williams categorized these examples and commented on them.

\footnotetext{
${ }^{3}$ http://lauhakan.home.cern.ch/lauhakan/int/cerpint.html (accessed: 29.11.2018).
}

4 https://www.duchas.ie (accessed: 28.11.2018). 
Georgy Kapchits (Russia) is a unique expert in the Somali language; he gives Somalia a romantic definition as a country of poets and pirates. Being a follower and a collaborator of the Russian scholar Grigory Permyakov, Kapchits investigates the poetic aspects of the Somali society. His paper presented this year in Tavira is entitled "On the artistic features of Somali proverbs" and pays special attention to the creative phonetic forms used in proverbs: alliteration, opposition of short and long, stressed/non-stressed vowels, phonetic parallelism. The active use of alliteration determines the selection of images used in Somali proverbs and must be taken into consideration when translating them into other languages, says Kapchits.

The issue of animals in proverbs had been discussed more than once during the past Tavira Colloquiums. This year Outi Lauhakangas (Finland) contributed to this popular subject with her paper "The functions of animal metaphors in proverbs." The same animal can have opposite metaphoric functions even within the same group - for instance, domestic animals: the dog as man's best friend in one culture, meanwhile in another culture the dog eats excrements and should be kept far from people. In her research Lauhakangas browsed the categories of the Matti Kuusi international type system of proverbs in order to understand which categories of the system mainly contain the animals-related proverbs.

We can see that Matti Kuusi's type system - alongside with Permyakov's classification system - was mentioned in multiple papers, as part of the basics in paremiology. The report entitled "The importance of the Matti Kuusi international type system of proverbs for the contrastive Slavonic paremiology" introduced by Marina Yu. Kotova (Russia) was fully devoted to the role of the international proverb computer database of the Finnish paremiologist in the contrastive inter-Slavic and Slavic-non-Slavic paremiography. She referred to the influence of the dialogue between Kuusi and Permyakov on the development of this database, underlined the significance of Permyakov's semiotic approach to paremiology and the theory of paremiological minimum, inspired by the ideas of Kuusi, for such theoretical issues as the revealing of the invariant of the proverb, fundamental principles of the thematic differentiation of proverbs, the very concept of the international paremiological core. The presentation included also a brief overview of the problems raised in the original discussion between the two paremiologists on the background of the recent achievements in Russian and Czech paremiology and paremiography, for example the research of her paremiological group at St. Petersburg State University.

Irina Zimonyi-Kalinina (Hungary) in her paper "Hungarian proverbial parallels of the Russian-English paremiological core" reported the outcome of identifying Hungarian parallels to the 450 items in the multilingual handbook of proverbs issued by Kotova. As a result, approximately $85 \%$ of the Russian-English proverbs were linked to their Hungarian parallels - fully, word for word, or by the same meaning expressed in dissimilar images. The opposite proverbs represented some $5 \%$, and the lacunae made up $9 \%$ of the material examined. Additionally, Zimonyi-Kalinina drew attention to the so-called Hungarikum proverbs, whose imagery contains very specific Hungarian phenomena: "The Hungarian is smart after the battle," "More was lost at Mohács," "Nobody is forced to attend the dinner given after killing the pig." She also mentioned the strong inspirational influence of the Matti Kuusi international type system of proverbs on her research.

Maslina Ljubičič (Croatia) attempted to create a logical link between grammar and the thematic group of proverbs dealing with imageries of kinship, presenting a paper "Grammatic gender and conceptualisation through kinship imagery in the language prov- 
erbs." The research on corpora of proverbs in various languages that have the category of gender disclosed the common origin of some well-known kinship metaphors. Most probably it derives from ancient Greek where the choice between the female or male kin is determined by the grammatic gender ("Greed is the mother of all evil"). The gender of the noun used in proverbs in the examined - Latin and other mostly Roman - languages conditions the choice of the female or male kin in the kinship metaphor ("Time is the father of all," "The earth is the common mother of all mortals," "Hate is the husband and revenge is his wife").

\section{Proverbs and newspapers}

Although proverbs are often considered a repository of the long-standing folk wisdom, and even a part of speech of older people, they do find their application in the presentday reality, in press and in new technologies. We already mentioned Kučera, who gathered proverbs in Rudé parvo, the official daily of the Communist Party of the immediate past. Jonathan Roper (Estonia) in his presentation "Ascriptions on locality to proverbs: What they might mean?" questioned the accuracy of ascription in the British Newspaper Archive (1708-2018) of the 363 proverbs marked as "Sussex" or "Devon." Elena Tomašková (Czech Republic) contributed a paper on "Ukrainian paremias in modern Russian political journalism," and Liisa Granbom-Herranen (Finland) examined "Contemporarily used proverbs in SMS messages sent to a Finnish daily paper" in Salo (2006-2010, approx. 70,000 SMSs).

\section{Proverbs and society}

In the presentation "What happens when proverbs meet change in public life?" Öznur Tuzcu (Turkey) touched upon the changes going on in the modern Turkish society. The multicultural society, the development of internet technology, the consumerism rather than traditional values, the increasing individualism and self-interest play a significant role in changing the proverbs. In the course of transformation, anti-proverbs are created by changing the meaning and the structure of the traditional proverbs in order to express new wisdom: "Look at the mother and be beaten by father," "Don't buy a house, marry a woman who has a house," "Speech is silver. Social media is gold." The Turkish anti-proverbs, says Tuzcu, reveal that in the consumerist society the values such as frugality, benevolence and patience are losing their meaning, and fixed phrases/proverbs can be changed according to the communication needs.

A very impressive social study was presented by Rethabile Possa (South Africa): "Rape culture: Are our proverbs perpetuating it?" The behaviour model in the traditional South-African society - i.e. how to treat women - is inherited from fathers or brothers. Rapes were often silenced and denied, and martial rape was never regarded as such. Child rapes were swept under the carpet, and the proverbs were unluckily used to justify that: "It is not wrong to eat from the flock." The high rate of rapes and other forms of sexual violence in South Africa led to a range of policy interventions aiming to reduce the number of victims of such a crime. Unfortunately, the official communications until now call for measures to avoid becoming a victim, and not against committing the crime. 


\section{Legal application of proverbs}

Proverbs do play a significant role in the South-African society, as affirmed by Munzhedzi James Mafela (South Africa) in his presentation on "The role of proverbs in dispute management among the Vhavenda." A small minority group practicing polygamy, the Vhavenda, live in the northern part of South Africa, region of Limpopo. Proverbs are vital educational instruments among the Africans, and they relay on proverbs in conflict management. Disputes are not resolved by modern legal tools, the Vhavenda society believe in their proverbs and accept the judgment of elders.

The legal application of proverbs can be traced also in the European jurisprudence. Felipe Neto Lopes (Portugal) introduced "The principle pacta sunt servanda in the proverbial perspective." An old Latin brocardo ${ }^{5}$ pacta sunt servanda - a religious idea which came into force in the legal culture - is known and used by all the jurists of the world. This legal principle meaning that covenants must be fully complied with is codified in Portuguese law as well. But considering a dispute with trade unions, who referred exclusively to a single paragraph of the new labour agreement (increase of salaries), the Court chose as an argument another paremiological unit, this time a proverb: "Quem compra a carne tem levar o osso" — "Who buys the meat has to take the bone."

\section{Proverbs and education}

More participants underlined the role of proverbs in the educational process. A group of researchers from Portugal (Cecilia Falcão, Claudia Martins, Nazaré Cardoso) in their presentation entitled "Paremiological literacy must be given a new lease of life. Considerations on higher education students' competence of Portuguese paremiology" expressed the opinion that the ubiquity of information literacy has not yet come to incorporate phraseological and paremiological competences. With the participation of bachelor students, the researchers attempt to identify the paremiological minimum of the Portuguese language. In their survey, they use different testing methods: the identification of the phrases already known, the completion of phrases (beginning or end), the spontaneous writing down of known or used phrases, the interpretation of the phrases, the commentary on the phrases. Following the Portuguese paremiological minimum, the next goal is to test the students' foreign languages competence, namely English, German, Spanish and French.

Proverbs can be used in teaching foreign languages (Iva Svobodova [Czech Republic] - "The names of the days of the weeks in the Portuguese proverbs") and can even help young students to better understand the natural sciences (Georgia Trabidou [Greece] — "Biology in proverbs").

\section{Portuguese literature and theatre}

The Portuguese writer and recipient of the 1998 Nobel Prize in Literature, José de Sousa Saramago, was an atheist but in his works he was in continuous conversation about God, emphasizing the theopoetic human factor. Felipe Pires (Portugal) in "Paremiological

5 A brocardo is an old maxim, often by an ancient and/or leading law scholar, which has been enshrined within the corpus of legal guidelines, laying the foundation for today's judiciary practice. 
reflections on Saramago's compromise in Cain" presented Saramago's novel from 2009. The proverbs are considered by Pires as a reinforcement of Saramago's religious perception: "The life of a god is not as easy as you believe," "The path of deceit is born narrow but will always find who is willing to enlarge it." And Cain is the culmination of the anti-theology.

The great figure of Portuguese literature, Fernando Pessoa, was addressed in two presentations: by Manuel Avelino de Jesus "Fernando Pessoa: The economist and the liberal. A view from a selection of Portuguese proverbs" and by Maria do Céu Estibeira (Portugal) "Fernando Pessoa's proverbs and animal imagery," reflecting once more the popular subject of animals in proverbs - since about $50 \%$ of the 300 Portuguese proverbs selected by Pessoa to be translated into English refer to animals.

Theatre was given a considerable role in this year's Colloquium agenda. Up to the 18th century the Portuguese theatre mirrored the state of contemporary language more than purely literary texts - says José Camões (Portugal) in his paper "An exemplary theatre." He also presented a searchable database of 16th-century Portuguese plays, ${ }^{6}$ which provides links to thousands of proverbs and their variants.

Luis Gameiro (Portugal) in "The theater in the 18th-century court: Possibilities for a saying origin" spoke about the period of flourishing in the theatrical art accessible at that time exclusively to the royal court, and Katherine Butieri (Brazil) in "Proverbs in the theatrical play Jesus man, by Plínio Marcos" examined the role of proverbs in the Brazilian piece from 1978.

\section{Interdisciplinary contributions}

The interdisciplinary contributions to the Colloquium revealed many interesting aspects of paremiology in the everyday reality. Maria Beatriz Rocha-Trindade (Portugal) in her paper "Portuguese migrations - saving attraction policies" drew attention to the social fact of significant physical mobility of Portuguese people, moving outside the borders of country. The marketing strategy adopted by the Portuguese banks was aimed at capturing the savings of the emigrants through creating links of sentimental nature to the the country of origin, using symbols and expressions of national culture.

Valmor da Silva (Brazil) generated a discussion: "To beat or not to beat your children: Debate with biblical and current proverbs."

The hosts and organizers of the Colloquium, Marinela Soares and Rui Soares (Portugal), reported about the activities conducted by them to commemorate the 10 years of the International Association of Paremiology and the 12 years of the Colloquium ("Voices of wisdom - a journey through the seasons of an association's life"). Marinela and Rui are devoted ambassadors of paremiology in Portugal and take all the opportunities to spread their knowledge in various communities.

\section{Other}

On the margins of the Colloquium the participants were offered an interactive activity organized by Gina Salapata (New Zealand): finding similar or opposite proverbs to the international selection and sketching a proverb. The best drawing was awarded a prize.

${ }^{6} \mathrm{http}: / /$ cet-e-quinhentos.com/autores (accessed: 11.11.2018). 
During the weekend the participants had an opportunity to visit the local market place, where the shoppers can not only acquire fresh agricultural products, meat and seafood, but also learn from small billboards proverbial wisdoms such as "Quem vende sardinha come galinha" ("Who sells sardines eats hen").

The limits of this article unfortunately don't make possible an exhaustive descprition of the entire Colloquium, and many valuable contributions were left out. The family of paremiologists and other enthusiasts of proverbs took home from Tavira a huge amount of information, food for thought and inspiration. The Interdisciplinary Colloquium on Proverbs is looking forward to welcoming every old and new family member in 2019.

Irina Zimonyi-Kalinina 